\title{
Evaluation of Building Energy Savings According to the Thermal Performance Experiment of PCM Floor Heating System
}

\author{
In Sung Kang1, Sang Hoon Baek , Jin Chul Park ${ }^{2}$ \\ ${ }^{1}$ Graduate Student, Chung-Ang University \\ Heuksuk-Ro 84, Dongjak-Ku, Seoul, Korea \\ inskang57@gmail.com; tokyo21@hanmail.net \\ ${ }^{2}$ Professor, Chung-Ang University \\ Heuksuk-Ro 84, Dongjak-Ku, Seoul, Korea \\ jincpark@cau.ac.kr
}

\begin{abstract}
This study proposes a floor heating system utilizing phase change materials to reduce energy consumption and greenhouse gases in residential buildings compared to existing floor heating system. PCM floor heating system was developed by inserting PCM modules and PCM aluminium packages between mortar layer and insulation layer. Preferentially, aluminium containers with Phase change materials were analysed to evaluate the potential thermal performance for storing sensible and latent heat. After thermal performance experiment conducted by 3 different melting points of PCM, $37^{\circ} \mathrm{C}, 41^{\circ} \mathrm{C}$ and $44^{\circ} \mathrm{C}$, building energy saving effects were evaluated through energy simulation (Energy-Plus) of PCM floor heating system which was applied to residential building. The results of simulation were found that RT $44 \mathrm{PCM}$ (melting point is $44^{\circ} \mathrm{C}$ ) was adequate material to show thermal performance, and total energy was saved about $44.81 \mathrm{kWh}, 0.11 \mathrm{kWh}$ per square meter during winter, from October 1 to March 31.
\end{abstract}

Keywords: PCMs (Phase Change Materials), Building Energy Savings, Thermal Performance Experiment, Floor Heating System

\section{Introduction}

In recent years, 'energy saving' has become one of the primary aims of energy policy in many countries. In Korea that relies on imports for energy needs more than $90 \%$, especially, the efforts for energy saving are much more important. In case of building system in Korea, most of buildings use floor heating system (FHS). Due to low heat storage performance of existing FHS, however, it requires continuous hot-water supply for maintaining comfortable floor surface temperature leading to excessive energy consumption in building. Among the many ways to reduce energy consumption in buildings, PCMs (Phase change materials) are used with various building materials in order to increase thermal insulation property and their thermal mass.

Therefore, this study aimed at reducing heating energy by applying packing-type PCM to floor heating system for compensating the problems of existing FHS. Preceding researches were analysed to compute optimal temperature of floor and a thermal performance experiment was conducted by 3 different melting points of $\mathrm{PCM}, 37^{\circ} \mathrm{C}, 41^{\circ} \mathrm{C}$ and $44^{\circ} \mathrm{C}$. Lastly, building energy saving effects were evaluated through energy simulation of PCM floor heating system which was applied to residential building.

\section{Methodology}

\subsection{Developing PCM floor heating system}

PCM is a substance which is capable of storing and releasing large amount of energy through phase changes at a certain temperature. It has advantages in being able to adapt to various temperatures and being suitable for the fields of its usage and its purpose [1]. While FHS is organized in order with concrete, insulation, mortar and floor finishing as shown in Fig. 1 [2], PCM floor heating system was developed by inserting PCM modules and PCM aluminium packages between 
mortar layer and insulation layer as shown in Fig. 2. Considering height of light-weight aerated concrete of existing floor heating system, height of PCM module was adjusted to $10 \mathrm{~mm}$.

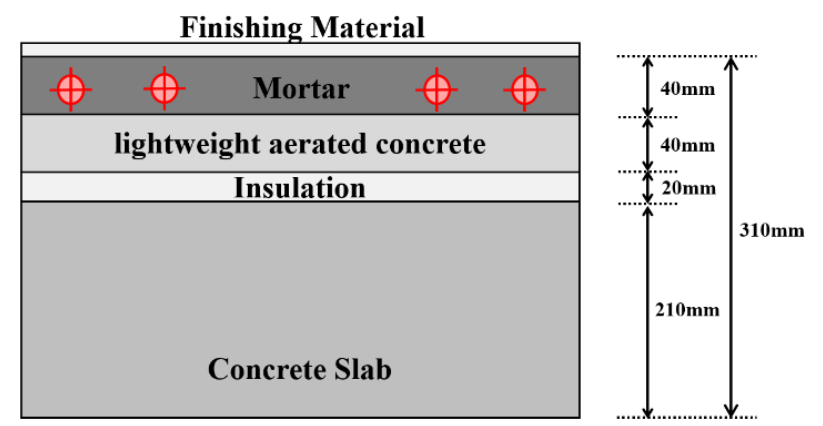

Fig. 1: Cross-sectional diagram of existing floor heating system.

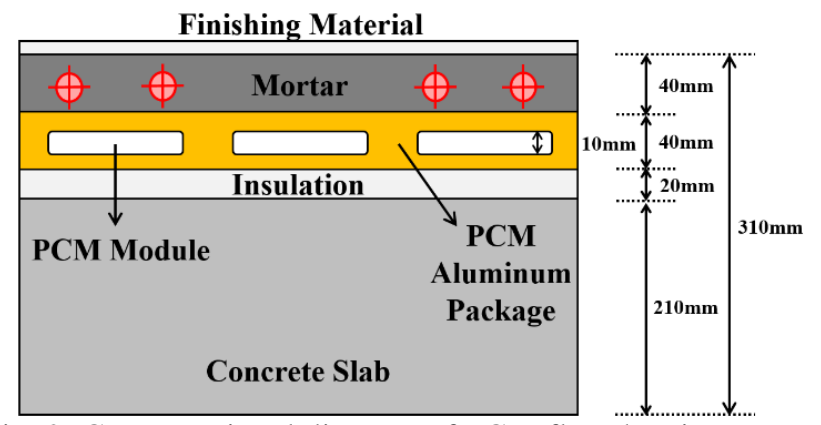

Fig. 2: Cross-sectional diagram of PCM floor heating system.

\subsection{Selecting melting points of PCM}

Assuming that the indoor temperature $1 \mathrm{~m}$ apart from the floor is $22^{\circ} \mathrm{C}$, formulas and mathematical model of calculating the temperature of PCM satisfying the range of comfortable temperature are as followings, Fig. 3, equation (1) and (2) [3].
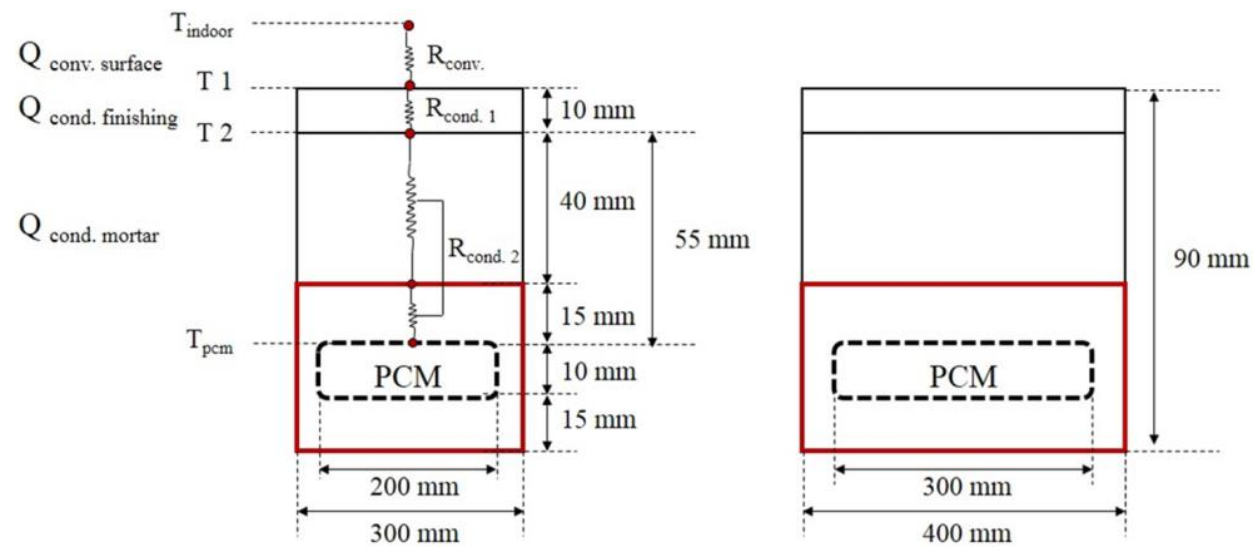

Fig. 3: Mathematical models of PCM floor heating system.

$$
\begin{aligned}
Q_{\text {cond. }} & =\frac{T_{\text {high }}-T_{\text {low }}}{R_{\text {cond. }}}[\mathrm{w}] \\
Q_{\text {conv. }} & =\frac{T_{\text {indoor }}-T_{1}}{R_{\text {conv. }}}[\mathrm{w}]
\end{aligned}
$$


The surface temperature distribution of each layers showed in the [Table 1] based on the calculation of [Formula 1] and [Formula 2]. As a result of calculation by different melting point of PCM $\left(32{ }^{\circ} \mathrm{C}, 35{ }^{\circ} \mathrm{C}, 37{ }^{\circ} \mathrm{C}, 41^{\circ} \mathrm{C}, 44{ }^{\circ} \mathrm{C}\right)$, the range of comfortable temperature on floor surface was from $26.2^{\circ} \mathrm{C}$ to $31.1{ }^{\circ} \mathrm{C}$. According to the results of preceding research [4-5] about comfortable surface temperature of floor heating system that the temperature range was from $28^{\circ} \mathrm{C}$ to $31^{\circ} \mathrm{C}, 3$ types of $\mathrm{PCM}$ which melting point is $37^{\circ} \mathrm{C}, 41^{\circ} \mathrm{C}$ and $44^{\circ} \mathrm{C}$ were found to satisfy the comfort range.

Table 1: Calculation results of surface temperature of each layers.

\begin{tabular}{|c|c|c|c|c|}
\hline No. & $\begin{array}{c}\text { Indoor } \\
\left({ }^{\circ} \mathrm{C}\right)\end{array}$ & $\begin{array}{c}\text { Floor surface } \\
\left({ }^{\circ} \mathrm{C}\right)\end{array}$ & $\begin{array}{c}\text { Mortar surface } \\
\left({ }^{\circ} \mathrm{C}\right)\end{array}$ & $\begin{array}{l}\text { Melting point of } \\
\operatorname{PCM}\left({ }^{\circ} \mathrm{C}\right)\end{array}$ \\
\hline 1 & \multirow{5}{*}{22} & 26.2 & 29.1 & 32 \\
\hline 2 & & 27.4 & 31.1 & 35 \\
\hline 3 & & 28.2 & 32.4 & 37 \\
\hline 4 & & 29.1 & 35.3 & 41 \\
\hline 5 & & 31.1 & 37.4 & 44 \\
\hline
\end{tabular}

\subsection{Thermal Performance Experiment}

A thermal performance experiment of 3 types of PCM selected by calculation results was conducted in a thermostatic chamber with a size of $450 \mathrm{~mm} \times 550 \mathrm{~mm} \times 500 \mathrm{~mm}$ [Fig. 4]. 3 types of different PCM of which melting point is $37^{\circ} \mathrm{C}$, $41^{\circ} \mathrm{C}, 44^{\circ} \mathrm{C}$ respectively was covered with aluminium to approve heat conductivity and the weight of each packing-type PCMs is equally $500 \mathrm{~g}$ [Fig. 5]. Then, the temperature change of PCM was measured by setting thermostatic chamber from $5^{\circ} \mathrm{C}$ to $55^{\circ} \mathrm{C}$.
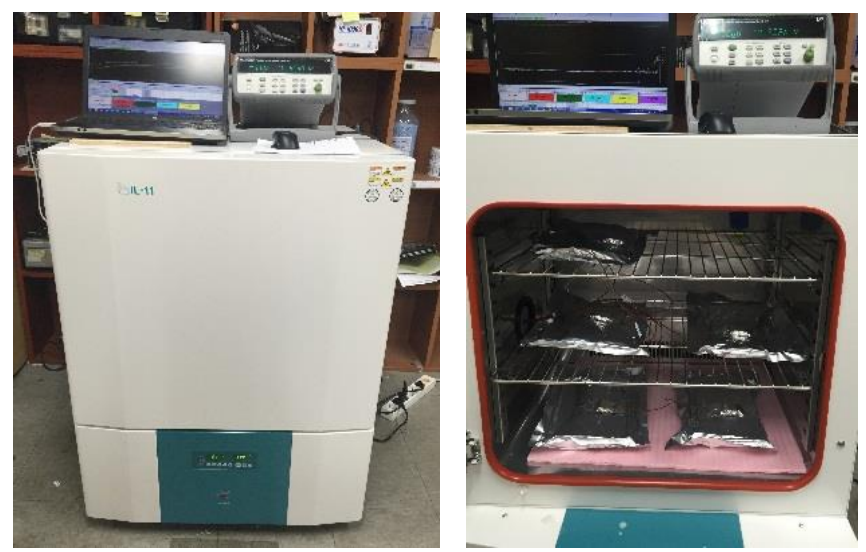

Fig. 4: Thermal performance experiment by thermostatic chamber.
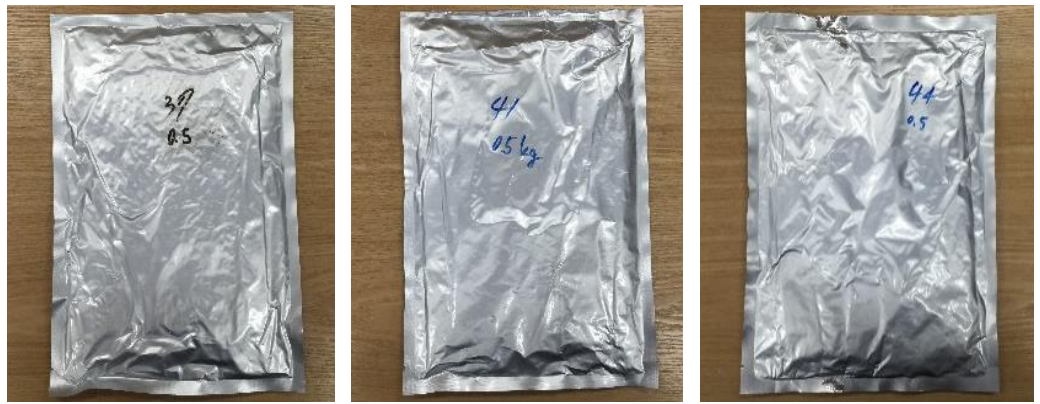

Fig. 5: Packing-type PCM. 


\subsection{Energy Simulation}

A general residential building model in Korea was analysed by Energy-Plus as shown in [Table 2]. PCM floor heating system and existing floor heating system which was applied to residential building were compared to evaluate energy saving effects in winter, from October 1 to March 31. Input data of outer walls, windows, roofs, HVAC systems, weather data and schedules are set under the same conditions presented in Energy-Plus examples.

Table 2: Overview of simulation model.

\begin{tabular}{|c|c|c|}
\hline Item & Factor & Simulation Model \\
\hline Story height & $3.6 \mathrm{~m}$ & \\
\hline Area & $400 \mathrm{~m}^{2}$ & \\
\hline Total area & $400 \mathrm{~m}^{2}$ \\
\hline Direction & South \\
\hline
\end{tabular}

\section{Results}

\subsection{Thermal performance measurement of PCM}

[Fig. 6] showed a pattern of temperature change by PCM type. Packing-type PCM got sensible heat from $5^{\circ} \mathrm{C}$ until constant temperature which means melting points of PCM. From this section, about 30 minutes later, PCM started to store the latent heat. After saturation point, PCM stored sensible heat again forming thermal equilibrium with indoor air temperature of thermostatic chamber. Above all, $\mathrm{PCM}$ with meting point $44^{\circ} \mathrm{C}$ shown to be having more time to store latent heat than other types of PCM.

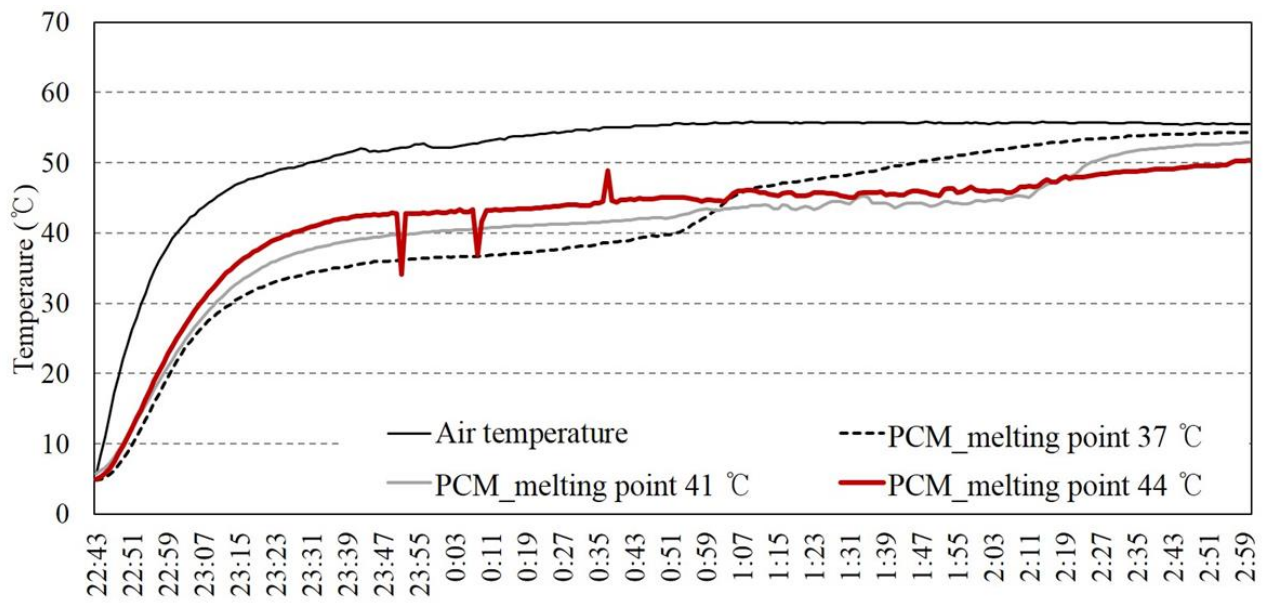

Fig. 6: Temperature changes of packing-type PCM.

\subsection{Results of Energy savings}

The results of energy simulation was carried out with comparing the heating energy consumption of residential building adopted by PCM heating floor system and normal heating floor system. As shown in [Table 3], total energy was saved about $44.81 \mathrm{kWh}$ and $0.11 \mathrm{kWh}$ per square meter during winter, from October 1 to March 31. Especially, heating energy savings was $30.23 \mathrm{kWh}$ taking portion of $67.5 \%$ to total energy savings. 
Table 3: Energy consumption of FHS and PCM FHS.

\begin{tabular}{|c|c|c|}
\hline & $\begin{array}{c}\text { Normal Floor } \\
\text { Heating System }\end{array}$ & $\begin{array}{c}\text { PCM Floor } \\
\text { Heating System }\end{array}$ \\
\hline Total Energy & $51174.28 \mathrm{kWh}$ & $51129.41 \mathrm{kWh}$ \\
\hline Energy per $\mathrm{m}^{2}$ & $128.04 \mathrm{kWh}$ & $127.93 \mathrm{kWh}$ \\
\hline
\end{tabular}

\section{Conclusion}

This study developed the floor heating system utilizing phase change materials to reduce energy consumption and greenhouse gases in residential buildings compared to existing floor heating system. Thermal performance experiment on PCM was conducted to figure out the adequate type of PCM, and energy saving effects of PCM floor heating system were analysed by energy simulation during winter. And the conclusions can be drawn as follows:

(1) According to the results of preceding research* about comfortable surface temperature of floor heating system that the temperature range was from $28^{\circ} \mathrm{C}$ to $31^{\circ} \mathrm{C}, 3$ types of PCM which melting point is $37{ }^{\circ} \mathrm{C}, 41{ }^{\circ} \mathrm{C}$ and $44{ }^{\circ} \mathrm{C}$ were found to satisfy the comfort range.

(2) PCM with meting point $44^{\circ} \mathrm{C}$ shown to be having more time to store latent heat than other types of PCM.

(3) In case of using PCM floor heating system, total energy was saved about $44.81 \mathrm{kWh}, 0.11 \mathrm{kWh}$ per square meter and heating energy savings was $30.23 \mathrm{kWh}$ taking portion of $67.5 \%$ to total energy savings during winter, from October 1 to March 31.

\section{Acknowledgements}

This study is a part of research by the fund supporting of national research foundation of Korea (NRF). Research number is 20160486.

\section{References}

[1] H. Kim, S. Bang, J. Park, E. Rhee, "A study on reducing cooling load using PCM \& Cool Roof," The Society of Airconditioning and Refrigerating Engineers of Korea, vol. 319, 2015.

[2] C. Lee, "Standard for noise prevention of floor impact sound isolation," Ministry of Land, Infrastructure and Transport, pp. 55-70, 2015.

[3] T. Akihiro, C. Yoon, "A comparative study on thermal responses of male and female in thermal environmental conditions in floor heating system," Architectural Institute of Korea, vol. 15, no. 5, pp. 127-134.

[4] A. C. Yunus, Introduction to Thermodynamics \& Heat Transfer, Inter Vision Co., Ltd., pp. 20-36.

[5] RUBITHERM, [Online]. Available: http://www.rubitherm.eu/en/ 